\title{
OLAHRAGA PASCA MELAHIRKAN
}

\author{
Oleh: Sri Winarni \\ Dosen Jurusan Pendidikan Olahraga FIK UNY
}

\section{Abstrak}

Setelah melahirkan, hal yang paling ingin cepat dilakukan oleh seorang wanita adalah kembali berolahraga untuk mendapatkan tubuh yang diinginkan. Tetapi banyak pula ibu-ibu pasca melahirkan malah takut untuk bergerak, takut terjadi robekan pada jahitan. Hal ini terjadi karena kekurangtahuan akan pengetahuan kapan dan olahraga apa yang dapat dilakukan seorang ibu pasca melahirkan.

Pasca melahirkan terjadi perubahan-perubahan pada rahim, vagina, dinding perut. Seorang wanita dapat kembali berolahraga ringan setelah dua minggu bagi yang melahirkan secara vaginal, dan enam minggu bagi yang melahirkan secara bedah caesar

Dua minggu pertama dapat melakukan latihan Kegel untuk menguatkan lubang vagina, berjalan, atau yoga yang paling halus. Setelah dua minggu dapat ditambah dengan peregangan dan jalan, bergoyang mengikuti irama musik dengan menggendong bayi.

Kata Kunci: pasca melahirkan, olahraga kegel

Sebagian besar wanita hamil pasti mengalami kenaikan berat badan. Kenaikan berat badan ini digunakan untuk meningkatkan kadar lemak ibu. Payudara, rahim/uterus akan membesar seiring dengan pertumbuhan janin. Otot-otot tubuh dan volume darah juga mengalami peningkatan, begitu pula plasenta dan air ketuban. Kenaikan berat badan ibu mempengaruhi tumbuh kembangnya janin karena selama di dalam kandungan janin mengandalkan nutrisi dari makanan yang ibu makan. Bila sebelum hamil berat ibu ideal, umumnya ketika hamil ibu akan mengalami kenaikan berat badan 8-15 kg (http://anakbayi.com/ artikel/mencegah-gendut-dan-loyo-sesudah-melahirkan). Studi lain menunjukkan bahwa kebanyakan wanita mendapatkan rata-rata sekitar 30 pound (dalam $\mathrm{kg}$ : $15 \mathrm{~kg}$ ) selama kehamilan, walaupun banyak dari kita akhirnya memperoleh lebih banyak dari itu. Ratarata, 18 - 20 pound (dalam kg: 9-10 kg) yang biasanya hilang dalam waktu satu bulan setelah melahirkan, tapi untuk menyingkirkan berat badan tambahan itu bisa jadi sulit. 
Permasalahan yang umum dihadapi oleh wanita yang baru melahirkan adalah mengembalikan berat badan pada berat badan semula atau berat badan ideal. Banyak wanita yang gagal melakukan hal ini, sehingga semakin banyak anak yang dilahirkan semakin gemuk juga sang ibu. Masalah ini seharusnya tidak perlu terjadi bila memperhatikan beberapa hal selama kehamilan dan setelah kehamilan (Paige Waehner, 2007).

Ada mitos yangmengatakan bahwa wanita hamil harus makan dua kali lipat untuk memberi nutrisi pada janin dan ibunya. Mitos ini yang mensugesti ibu untuk makan banyak selama hamil padahal pendapat ini tidak benar, yang benar adalah ibu mengkonsumsi makanan secukupnya dan gizi yang seimbang agar mencukupi kebutuhan ibu dan bayi. Jumlah kalori yang diperlukan oleh ibu yang sedang hamil adalah $2600-2900$ kalori per hari.

Setelah melahirkan pada umumnya akan mengalami penurunan berat badan secara bertahap karena meningkatnya aktivitas fisik ketika merawat bayi. Sehingga tanpa diet ketatpun seharusnya berat badan bisa kembali ideal. Namun tidak semua wanita mengalami hal itu bahkan ada yang masih bertambah berat badannya sewaktu menyusui. $\mathrm{Hal}$ ini disebabkan ibu sering makan ditengah malam sewaktu bangun untuk menyusui. Kemungkinan lain adalah sebelum hamil berat badan sudah di atas berat ideal. Kemungkinan yang laín lagi adalah tidak melakukan olahraga setelah melahirkan.

Latihan fisik atau olahraga teratur dapat meningkatkan kesehatan jasmani dan rohani seseorang secara menyeluruh. Metabolisme tubuh akan membaik. Segi fisik, mental, dan sosial akan lebih terasa harmonis. Dalam kaitannya membentuk tubuh ideal, latihan fisik merupakan kunci untuk mempertahankan berat badan ideal. Latihan fisik juga menurunkan kadar kolesterol total dan diduga memperkuat daya tahan tubuh terhadap penyakit. Sebagian manfaat tersebut hanya tampak jika latihan fisik dilakukan secara teratur, dengan formula sederhana, yaitu frekuensi latihan, porsi latihan, lama latihan, dan jenis latihan.

Kapan olahraga dapat dilakukan lagi setelah melahirkan, olahraga yang bagaimana yang boleh dilakukan.

\section{PERUBAHAN PASCA MELAHIRKAN}

Berbagai perubahan anatomis dan fungsi faal tubuh yang terjadi dari fase kehamilan ke fase pasca melahirkan, yang memerlukan kondisi khusus untuk membantu melalui fase ini. Ketika setelah bayi lahir, tubuh ibu akan kembali mengalami perubahan, yaitu akan kembali seperti keadaan sebelum hamil. Menurut dr Jeffry Beta Tenggara beberapa perubahan anatomis yang terjadi antara lain: (1) jaringan dan ligamen di area perut, pinggul, lutut mulai mengecil karena terjadi penurunan kadar hormon dalam darah, (2) pada ibu yang menyusui, terjadi kondisi yang mirip seperti keadaan menopause karena hilangnya fungsi ovarium. Kondisi ini ditandai dengan tidak adanya menstruasi, vagina dan kulit menjadi kering, kehilangan mineral tulang, ukuran payudara membesar, sehingga memerlukan penyangga yang sesuai dan yang paling penting adalah instabilitas emosional, (3) rasa sakit paska operasi caesar (walau ini hanya terjadi pada sebagian saja), (4) kebutuhan cairan yang meningkat selama fase menyusui. Selain itu juga terjadi perubahan psikologis 
pada fase ini, yang disebabkan oleh: (1) perubahan pola tidur (bangun pada malam hari untuk menyusui atau sekedar mengganti popok), (2) instabilitas emosional karena perubahan pola hormonal.

Sejalan dengan itu Indiarti (2009:37) menyebutkan perubahan-perubahan yang terjadi setelah persalinan, antara lain pada: (1) rahim. Setelah terjadi persalinan, rahim akan kembali mengecil keukuran semula. Proses kembalinya rahim ke ukuran semula disebut involusi. Proses involusi ini terjadinya secara berangsur dan cepat. Ukuran rahim akan mencapai berat semula, yaitu sekitar hari ke 42 setelah persalinan.

Tabel 1: Berat Rahim Setelah Persalinan

\begin{tabular}{|l|l|}
\hline Hari ke & Berat rahim \\
\hline 7 & 500 gram \\
\hline 14 & 375 gram \\
\hline 42 & 50 gram \\
\hline
\end{tabular}

Selaín terjadi proses mengecilnya ukuran dan berat rahim, juga terjadi proses penyembuhan rahim. Proses penyembuhan rahim berupa tertutupnya tempat implantasi plasenta dengan epitel. Penutupan tempat implantasi terjadi karena rahin berkontraksi. Dengan berkontraksinya rahim maka pembuluh darah akan terjepit, sehingga pendarahan pun berhenti. Hal ini juga disebutkan akan menghindarkan dari terjadinya infeksi rahim, (2) Vagina. Sel-sel vagina merupakan sel yang bersifat elastis. Karena itu pada proses persalinan memungkinkan terjadinya peregangan, sehingga bayi dapat keluar melalui lubang vagina. Setelah persalinan, lubang vagina akan mengecil, kira-kira satu minggu setelah persalinan, lubang vagina hanya dapat dilalui 1 jari. Selain itu robekan pada lubang vagina juga akan sembuh dengan sendirinya, hanya robekan yang terdapat pada mulut rahim yang memerlukan perhatian. Bisa jadi robekan pada mulut rahim ini sulit sembuh dan dapat menjadi luka menahun (kronis), sehingga memungkinkan menjadi sumber infeksi atau dapat mengalami degenerasi ganas, (3) Dinding perut. Selama kehamilan, otot dinding perut akan memanjang sesuai dengan besarnya pertumbuhan kehamilan. Setelah persalinan dinding perut akan menjadi kendor, dan lebih kendor sesuai dengan jumlah kehamilan.

\section{PERLUNYA OLAHRAGA SETELAH MELAHIRKAN}

Berolahraga cukup dan mengurangi makanan berlemak selama kehamilan, akan menyebabkan ibu cepat langsing kembali sesudah melahirkan. University of Pittsburgh Medical Center telah melakukan test terhadap 110 ibu hamil yang sebelum hamil mempunyai berat badan normal. Separuh diantaranya, diharuskan jalan selama 20 menit setiap hari, mengkomsumsi susu rendah lemak, dan makan makanan yang tidak mengandung lemak jenuh. Sementara, 50 persen sisanya, tidak melakukan olahraga dan boleh makan 
sesukanya. Hasilnya, 67 persen golongan pertama, kembali ke berat badan semula, atau terjadi penambahan hanya sampai 5 kilogram pada bulan pertama sesudah kehamilan. Sebaliknya, ibu-ibu dari golongan pertama, mengalami kenaikan di atas 7 kilogram dan selama berminggu-minggu berikutnya, tetap kesulitan menurunkan berat badan idealnya. Sayangnya, riset ini tidak melakukan studi terhadap wanita-wanita yang sebelumnya sudah overweight ( http://anąkbayi.com/artikel/mencegah-gendut-dan-loyo-sesudah-melahirkan).

Berjalan kaki selama 30 menit akan membakar kalori sebesar $100-150$ kal. Selain itu, $40 \%$ otot tubuh disimpan di kaki dan sebagian kalori disimpan di otot. Jadi makin banyak jalan kaki, maka kalori yang dibakar juga makin banyak. Selain menurunkan berat badan, olahraga ringan juga bertujuan untuk menguatkan otot panggul, dasar panggul, paha hingga mengencangkan otot perut yang mengendur. Olahraga juga memicu aktivitas jantung, sehingga pernafasan menjadi lebih baik.

Memulai program latihan dengan intensitas moderat pasca melahirkan bermanfaat dalam banyak hal. Olahraga teratur meningkatkan fungsi kekebalan dan meningkatkan produksi zat antioksidan dalam tubuh (Kelly Camden, 2008). Lebih lanjut dijelaskan bahwa olahraga akan membantu untuk tidur lebih nyenyak di malam hari dan merasa lebih bertenaga sepanjang hari. Jalan cepat adalah cara yang tepat bagi depresi atau kecemasan. Olahraga juga membantu untuk menekan nafsu makan pada permen dan junk food dan meningkatkan nafsu makan malam, makanan bergizi. Kelentukan dan kekuatan otot tidak seimbang mencegah ketegangan pada kerangka yang dapat menyebabkan rasa sakit dan luka dari waktu ke waktu. Jika otot-otot kuat dan sendi-sendi lentur, maka tidak akan terjadi cidera saat mengangkat, membungkuk, memutar, dan kegiatan rutin lain sehari-hari.

Latihan adalah hal yang sangat baik bagi ibu, namun jika dosis latihan terlalu banyak atau cepat bisa berbahaya. Hal ini terutama berlaku bagi perempuan yang rendah hormon adrenal kortisol. Ketika berolahraga, keluar pompa kelenjar adrenal kortisol untuk meningkatkan denyut jantung dan laju pernapasan, dan untuk meningkatkan aliran darah ke otot-otot. Ada penurunan yang signifikan dalam kadar kortisol setelah melahirkan. Pergi keluar untuk berjalan dua minggu setelah melahirkan akan menggunakan sumber daya yang merangsang adrenal keluar sebelum mereka siap, dan ini akan menyebabkan tubuh menjadi tidak seimbang. Jika tes laboratorium menunjukkan bahwa kadar kortisol rendah, maka harus menunda olahraga tapi mungkin olahraga ringan sampai level tersebut kembali normal.

\section{WAKTU DIMULAINYA OLAHRAGA}

Beberapa pendapat menyatakan berbeda, seperti Kelly Camden seorang instruktur yoga, menyebutkan bagi ibu yang melahirkan secara vaginal setelah tiga minggu bisa berolahraga ringan dan enam minggu bagi yang melahirkan melalui caesar, namun tetap tergantung dari kondisi masing-masing, bahkan beberapa wanita membutuhkan waktu lebih lama. Senada dengan itu Indarti (2009: 48) menyebutkan, ibu yang baru melahirkan secara normal biasanya akan diperbolehkan berolahraga sekitar 40 hari setelah melahirkan, sedangkan bagi ibu yang melahirkan dengan jalan bedah caesar baru boleh berolahraga 
sekitar tiga bulan setelah melahirkan. Menurut Kirschner (dalam bukunya Yoga untuk Kesehatan dan Kekuatan), setiap kelahiran meninggalkan luka dalam rahim ibu yang memerlukan waktu untuk penyembuhan. Ini dapat terjadi dengan cepat, mungkin dalam dua minggu atau bahkan memerlukan waktu beberapa bulan. Selama itu istirahat adalah hal yang paling berguna.

Beberapa pẹndapat menyebutkan olahraga dapat dilakukan lebih awal, yaitu satu minggu setelah melahirkan baik normal atau lewat operasi, seorang wanita sudah diijinkan untuk berolahraga. Tentunya jenis olahraga yang low impact, seperti berjalan kaki selama 30 menit, sedangkan olahraga yang bigh impact belum boleh dilakukan karena dapat mengakibatkan pendarahan. (http://anakbayi.com/artikel/mencegah-gendut-dan-loyo-sesudah-melahirkan).

$\mathrm{Hal}$ penting yang harus diingat tentang olahraga pasca melahirkan adalah bahwa tidak boleh memulai terlalu cepat. Ada pendapat yang saling bertentangan mengenai hal ini. Beberapa ahli menyarankan menunggu enam minggu untuk melakukan latihan, sementara yang lain mengatakan bahwa olahraga bagi ibu yang baru melahirkan, dapat dimulai sesegera sehari setelah melahirkan. Dalam beberapa kasus yang jarang, perempuan yang benar-benar cukup baik untuk bangun dan berjalan jarak pendek sehari setelah melahirkan. Ini mungkin benar untuk wanita yang telah melahirkan beberapa kali sebelumnya, dan yang tubuhnya digunakan untuk transisi ke melahirkan. Sebaliknya wanita yang telah melahirkan dengan rumit dan sulit pemulihan, mungkin memerlukan enam minggu penuh istirahat sebelum melakukan aktivitas dengan penuh semangat. Kebanyakan wanita, berada pada kondisi di antara keduannya. Sehingga direkomendasikan bahwa ibu beristirahat dan memulihkan diri selama dua minggu penuh setelah melahirkan.

Selama kehamilan peningkatan derajat fleksibilitas, sendi-sendi masih akan longgar selama beberapa minggu pertama setelah melahirkan, dan berarti risiko cedera, seperti lepas ligamen lebih besar. Berolahraga terlalu keras dalam minggu-minggu pertama itu juga dapat menunda penyembuhan episiotomi (penjahitan) pada operasi caesar. Jika hemorrhaged (terjadi perdarahan) setelah melahirkan, mungkin menderita anemia, dan akan perlu untuk membangun kadar zat besi untuk sementara waktu sebelum siap untuk berolahraga.

\section{OLAHRAGA RINGAN DUA MINGGU PERTAMA PASCA MELAHIRKAN}

Tujuan utama pada fase ini adalah menemukan pola latihan yang sesuai dengan kondisi individual dan ditingkatkan hingga titik optimal. Pastikan berkonsultasi terlebih dahulu dengan dokter sebelum melakukan aktivitas olahraga, karena tiap orang memiliki kondisi medis yang berbeda. Memperhatikan perubahan-perubahan yang terjadi akibat kehamilan, maka latihan harus menjadi proses bertahap. Pasca melahirkan tubuh telah mengalami perubahan yang sangat besar dan dibutuhkan waktu pulih kembali. Beberapa saran yang dianjurkan oleh Indiarti, (2009: 68) dan Kelly Camden \& Paige Waehner (2007) adalah: (1) Latihan Kegel. Latihan Kegel melibatkan kontraksi kecil membuat otot di dinding 
vagina. Latihan-latihan ini dapat membantu memperkuat otot-otot panggul yang lemah, yang dapat menyebabkan masalah kontrol kandung kemih, yang sering terjadi pada wanita setelah melahirkan. Inilah latihan dasar kegel: Kontraksikan otot-otot vagina seolaholah menahan aliran urin, dan tahan sepuluh detik. Kemudian relaks. Lakukan ini setiap kali berpikir untuk melakukannya, lakukan hingga lima set dari sepuluh pengulangan tiga sampai empat kali sehari. Kegel membantu darah tetap mengalir ke daerah genital dan perineum, mendorong tubuh anda untuk menyembuhkan dari robek, bengkak, atau memar. Latihan kegel dapat dilakukan segera setelah hari melahirkan, (2) Berjalan. Berjalan lambat dapat membantu mempersiapkan tubuh untuk lebih giat latihan, dan juga mendapatkan udara segar. Berjalan setelah melahirkan sangat penting untuk mencegah trombosis vena (sumbatan vena oleh bekuan darah), (3) Yoga: pose yoga yang lembut bisa menjadi cara yang bagus untuk mendapatkan darah yang mengalir sambil mengurangi stres. Beberapa pose-pose perlu dihindari (seperti inversi), tapi dasar bergerak, seperti sikap jembatan, prajurit, miringkan pelvis, dapat dilakukan, (4) Pilates. Dengan beberapa modifikasi, mungkin juga dapat melakukan latihan Pilates dasar untuk memperkuat inti dan meningkatkan fleksibilitas. (http://exercise.about.com/cs/exercisehealth/a/ postpartumexer.htm)

Elisabeth Bing dan Libby Colman menggabungkan latihan sederhana peregangan dan gerakan dari yoga. Untuk hasil terbaik, lakukan latihan setiap hari selama 10 sampai 15 menit, yang dimulai setelah pasca kelahiran pertama pemeriksaan medis. Latihan ini dirancang untuk meningkatkan kekuatan otot, menyadari postur yang baik dan meningkatkan gaya lemah gemulai berjalan, juga akan memperkuat punggung dan otototot perut, sehingga dapat dengan mudah menangani meningkatnya berat badan bayi. Jika merasa sulit untuk melakukan semua latihan pada satu waktu, dapat dilakukan dalam dua periode latihan sekitar lima menit masing-masing. Latihan yang dimaksud adalah:

(1) Supple Spine. Mulai merangkak. Napas. Angkat kepala, menjaga punggung tetap lurus atau sedikit melengkung (menghindari regangan). Lalu buang napas, bulat punggung, kencangkan perut, selipkan di ekor dan kepala. Ulangi urutan delapan kali. Latihan ini memperkuat punggung dan perut.
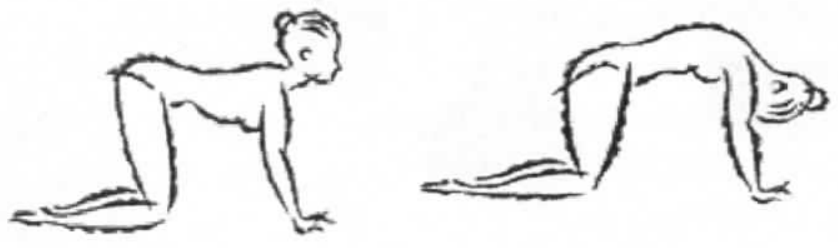

Gambar 1. Gerakan Supple Spine 
(2) Mengencangkan perut. Berbaring dalam garis lurus. Lalu menghembuskan napas, menurunkan punggung, ruas demi ruas. Ulangi urutan lima kali. Latihan ini membantu mengembangkan kembali kuat dan perut.
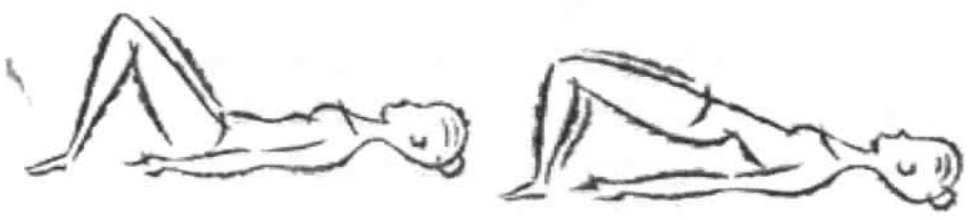

\section{Gambar 2. Gerakan Mengencangkan Perut}

(3) Penguatan punggung. Duduk tegak, lutut ditekuk, kaki mendatar di lantai, punggung tegak, lengan ke depan setinggi bahu. Tarik napas, lalu buang napas dan bersandar di tengah jalan. Tarik napas lagi dan duduk perlahan-lahan. Ulangi lima kali. Latihan ini memperkuat punggung dan perut.
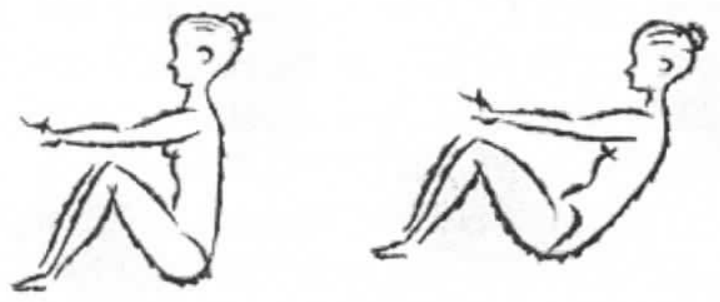

\section{Gambar 3. Gerakan Penguatan Otot Punggung}

(4) Melenturkan Tubuh. Berdiri tegak dengan lengan terangkat, siku sedikit santai. Tarik napas, lalu buang napas dan membungkuk ke depan, menjaga punggung lurus dan mengayunkan lengan ke bawah dan punggung. Kemudian relaks kepala dan meregangkan lengan di belakang punggung. Tarik napas saat kamu ayunkan lengan dan badan lagi, kembali ke posisi awal. Lakukanlah dengan hati-hati dan jangan tegang. Latihan ini baik untuk paha, pinggul, punggung, lengan, bahu dan leher.
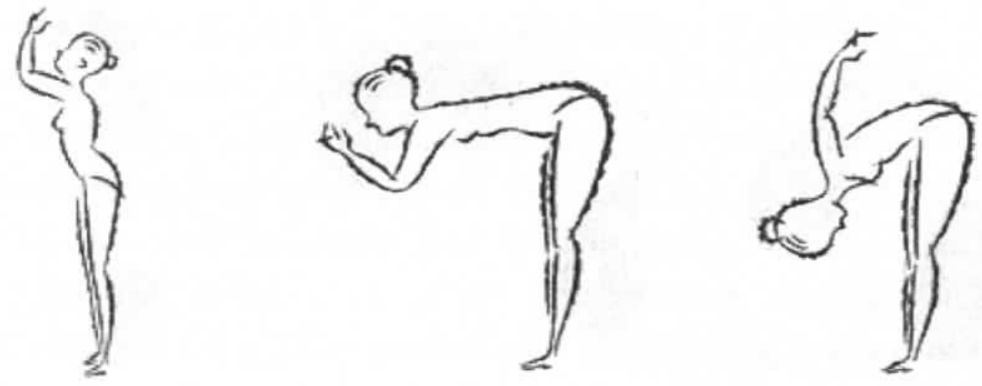

Gambar 4. Gerakan Melenturkan Tubuh 


\section{OLAHRAGA SESUDAH DUA MINGGU PERTAMA}

Setelah latihan di dua minggu pertama dirasakan cukup nyaman, maka pada minggu berikutnya, yaitu minggu ketiga dapat ditingkatkan latihannya dengan beberapa olahraga ringan, dengan tetap memperhatikan kondisi tubuh. Berjalan adalah latihan pertama yang baik bagi ibu dan bayinya. Letakkan bayi dalam kereta dorong atau carrier dan mulai berjalan. Mulailah dengan sebuah perjalanan sekitar rumah, dan secara bertahap meningkatkan jaraknya. Jika mungkin ikuti kelas yoga. Di rumah, dapat mulai melakukan latihan penguatan dan peregangan satu sampai tiga kali sehari, sementara bayi tidur atau menghabiskan waktu bersama anggota keluarga lainnya.

Setelah memulai berolahraga, hal yang perlu diwaspadai adalah tanda-tanda bahwa mungkin usaha yang dilakukan saat olahraga terlalu keras. Dapat meningkatkan aliran lokhia (pendarahan) setelah sesi latihan, terutama pada bulan pertama setelah melahirkan. Artinya harus segera diturunkan beban kerjanya. Beberapa tanda-tanda lain yang harus diperhatikan adalah: Jika vagina, perineum, atau sayatan bedah caesar tidak sembuh dengan baik, jika payudara terlalu penuh dan sakit karena bra kurang mendukung, jika memerlukan tidur siang lebih dari yang dibutuhkan latihan, atau jika mengalami pusing atau kelelahan ekstrem, berhenti dan coba lagi besok atau lusa. Tidak perlu melakukan latihan secepat ini, tunda hingga tubuh siap. Bahkan beberapa ahli menganjurkan dua minggu setelah melahirkan digunakan untuk istirahat dan mengasuh bayi saja. Berikut ini latihan yang dianjurkan Kelly Camden (2008) untuk dilakukan di rumah dua minggu setelah melahirkan antara lain: (1) Push-Ups. Bertumpulah di tangan dan lutut. Turunkan dada ke lantai dan kemudian membawanya kembali. Coba lakukan satu set sepuluh kali dengan siku menunjuk ke luar (untuk kerja otot-otot dada), dan satu set dengan siku masuk ke pinggang (untuk kerja otot-otot di punggung tangan). Sebagian besar berat badan harus didukung pada lutut. Setelah minggu pertama, cobalah melakukan dua set masing-masing per sesi, (2) Shoulder Blade Squeeze. Latihan ini membantu untuk mencegah bahu tegang dan punggung atas akibat menggendong atau menyusui. Berdiri dengan kaki terbuka selebar pinggul atau duduk di sebuah kursi bersandaran lurus. Remas bahu ke bawah dan ke arah satu sama lain, lalu lepaskan. Lakukan hal ini sepuluh sampai dua puluh kali per sesi. (3) Head and Shoulder Lifts. Kebanyakan wanita memiliki diastasis, atau pemisahan dalam otot-otot perut, setelah melahirkan yang merasa seolaholah seseorang telah membuka ritsleting abs mereka di tengah-tengah dari atas ke bawah. Pemisahan ini dapat ditutup dengan penguatan yang tepat latihan perut. Sebelum mencoba apapun latihan otot perut, periksa untuk melihat bagaimana luas pemisahannya. Berbaring di punggung dan menyilangkan tangan di dada. Tarik napas dan perlahan-lahan angkat dagu ke arah dada dan meringkuk puncak bahu terangkat dari lantai. Bayangkan bahwa tubuh menekan otot-otot perut ke arah pusar. Tarik napas saat melepaskan kembali. Mulailah dengan sepuluh pengulangan dan lakukan sampai dua puluh kali per sesi. Untuk memeriksa diastasis, mengulurkan tangan dengan satu tangan saat menahan dagu dan bahu ke atas. Pegang tangan dengan telapak menghadap wajah dan menemukan jeda 
tepat di atas pusar. Mungkin dapat fit tiga atau empat jari ke dalam jurang. Jangan mencoba untuk melakukan "sit-up" (di mana mengangkat seluruh tubuh dari atas lantai) atau lain yang lebih berat lakukan sampai celah telah tertutup kurang dari tiga jari lebarnya. Memeluk pinggang dan memeluk kedua tepi jurang bekerja bersama sebagai abs akan membantu menutup celah, (4) Against - the-Wall Stretch. Berdiri menghadap dinding, sekitar satu lengan dari dinding. Genggam tangan dan membungkuk ke depan dari pinggul, lengan bawah menempel dinding. Jaga sedikit menekuk lutut dan siku sedekat mungkin sama seperti saat mengggeser lengan ke dinding. gerakan harus berakhir pada pinggul bengkok sekitar 90 derajat. Biarkan dada dan kepala tenggelam ke lantai dan bernapas dalam-dalam, (5) Punggung Kucing dan Anjing. Bertumpu pada tangan dan lutut, membuat punggung datar, seperti meja. Tarik napas dan melengkungkan punggung ke arah langit-langit, menyelipkan dagu ke arah dada dan tulang ekor antara kaki (ini adalah "punggung kucing" bagian dari latihan). Buang napas, kembali ke flat, netral tulang belakang. Tarik napas lagi ketika melengkungkan punggung ke arah lain, menengadah ke langit-langit dan menunjuk tulang ekor (yang "punggung anjing"). Kembali ke datar lalu kembali lagi saat menghembuskan napas. Ulangi ini beberapa kali. Bayi mungkin akan menikmati saat berbaring di bawah ibu, (6) Child's Pose. Pose yoga ini sangat baik untuk melepaskan ketegangan dari seluruh tubuh selama dan setelah kehamilan. Duduk dengan kaki dilipat di bawah, sehingga duduk di tumit dengan lutut berpisah. Lipat tubuh ke depan, sehingga badan tenggelam ke lantai di antara paha. Istirahat dengan lembut dahi di lantai. Dapat memperpanjang lengan atas kepala, ke luar ke samping, atau bawah ke arah kaki. Jika suka, dapat bersantai maju ke bantal. Lakukan selama masih nyaman, bernapas dalam-dalam untuk memungkinkan penarikan mendalam untuk memperluas bawah dan punggung atas. Saat tubuh sudah semakin kuat, dianjurkan memasukkan aktivitas aerobik dalam setiap harinya dalam beberapa cara. Suatu saat mungkin melakukan pekerjaan rumah tangga sepanjang hari, berjalan dan mengangkat dan membungkuk selama sepuluh menit pada suatu waktu.

\section{KESIMPULAN}

Pasca melahirkan terjadi perubahan-perubahan pada rahim, vagina, dinding perut. Seorang wanita dapat kembali berolahraga ringan setelah dua minggu bagi yang melahirkan secara vaginal, dan enam minggu bagi yang melahirkan secara bedah caesar. Dua minggu pertama dapat melakukan latihan Kegel untuk menguatkan lubang vaginà, berjalan, atau yoga yang paling halus. Setelah dua minggu dapat ditambah dengan peregangan dan jałan, bergoyang mengikuti irama musik dengan menggendong bayi. Perlu diperhatikan tandatanda dari tubuh jika latihan sudah terlalu berat, akan membahayakan bisa terjadi pendarahan, pusing, terasa ingin buang air kecil. Maka jangan ingin terlalu cepat berolahraga, lakukan secara bertahap hingga tubuh terasa nyaman. 


\section{DAFTAR PUSTAKA}

Bing, Elisabeth \& Colman, Libby. (2008). Easy Postpartum. Diakses pada Januari 2010 dari http://www.babies.sutterhealth.org/afterthebirth/newmom/ pp ppexercise.html

Camden, Kelly (2008) Postpartum Exercise, diakses pada Januari 2010 dari http:// www.babies.sutterhealth.org/afterthebirth/newmom/pp ppexercise.html.

Indiarti, M. T. (2009). Langsing dan Sehat Pasca Melabirkan Ala Selebritis. Yogyakarta: Genius Publisher.

Kirschner, M. J. (t.t). Yoga untuk Kesehatan dan Kekuatan. Bandung: CV. Pionir Jaya Bandung.

Tenggara, Jeffry (2008). Post Partum Back to Gym. Diakses pada 12 Februari 2010 dari http://exercise.about.com/cs/exercisehealth/a/postpartumexer.htm.

Waehner, Paige. (2007). Exercise After Baby. Diakses pada 12 Februari 2010 dari http:// exercise.about.com/cs/exercisehealth/a/postpartumexer.htm. 